\title{
НОВІ АЛГОРИТМИ ФРМ В СФЕРАХ ОСВІТИ І ПРАКТИЧНӦ̈ ДІЯЛЬНОСТІ НА ПІДГРУНТІ ВПРОВАДЖЕННЯ СИСТЕМИ «ТРАНСДИСЦИПЛІНАРНА ІНТЕЛЕКТУАЛЬНА ІНФОРМАЦЙНО--АНАЛІТИЧНА СИСТЕМА СУПРОВОДЖЕННЯ ПРОЦЕСІВ РЕАБІЛІТАЦІЇ ПРИ ПАНДЕМЇ̈» (ТІSР)
}

\author{
Владимиров О.А., Голик В.А.
}

\author{
Національний університет охорони здоров'я України імені П.Л. Шупика, кафедра фізичної та \\ реабілітаційної медицини і спортивної медицини, м. Київ, Украӥна
}

\begin{abstract}
Для кореспонденції: Владимиров Олександр Аркадійович, доктор медичних наук, завідувач кафедри фрізичної та реабілітаційної медицини і спортивної медицини Національний університет охорони здоров'я України імені П.Л. Шупика , контактний телефон: +380674660081, avladimirov05@gmail.com
\end{abstract}

Особливу роль в реалізації усіх функціональностей з реабілітації пацієнтів в умовах масштабної пандемії мають: підтримка інформаційно-аналітичних процесів збору та обробки даних; класифікація паціснтів за станом здоров'я; дослідження фундаментальних причин і наслідків виникнення кризових (пандемійних) ситуацій в країні й у світі; підтримка прийняття рішень на всіх рівнях державного управління, розробки і корекції загальної політики розвитку держави і окремих ії регіонів; надання інформаційно-консультативної допомоги населенню; методологічні засади відновлення та реабілітації у відповідності з рекомендаціями Білої Книги з Фізичної та Реабілітаційної Медицини в Европі, яка є ключовим Європейським довідником для спеціалістів усіх рангів: від лікарів до осіб, що приймають рішення на державному рівні в сфері охорони здоров'я. Протягом останніх років розвиток реабілітаційної допомоги та, зокрема, фізичної та реабілітаційної медицини (ФРМ) в Україні здобув потужного прискорення, Цей процес потребує систематизації збору даних по обмеженнях життєдіяльності та плануванню реабілітаційних послуг, а також індивідуальної оцінки обмеження життєдіяльності та постановки цілей реабілітації.

Таким чином, актуальним на сьогодні є створення Трансдисциплінарної інтелектуальної інформаційно-аналітичні системи супроводження (в тому числі в реальному часі) процесів реабілітації при пандемії, які вирішують комплекс проблем, пов'язаних з підвищенням ефективності боротьби з глобальними стихійними явищами, що загрожують життю людей і сталому розвитку суспільства.

Мета освоення системи «Трансдисциплінарна інтелектуальна інформаційно-аналітична система супроводження процесів реабілітації при пандемії» та впровадження ії розробок в навчально -освітних програмах лікарів.

В роботі використанні офіційні документи Всесвітньої організації охорони здоров'я, законодавчих актів у сфері охорони здоров’я та реабілітації України, Постанови Кабінету міністрів України, накази МОЗ України та інших міністерств, « Звіт І-го етапу НДР «Трансдисциплінарна інтелектуальна інформаційно-аналітична система супроводження процесів реабілітації при пандемії» (TISP), НФД України за 2020р., навчально - методичні матеріали кафедри фізичної та реабілітаційної медицини і спортивної медицини НУОЗ України імені П.Л.Шупика - шляхом їх аналізу, систематизування, прогнозування

В результаті роботи опрацьованно результати НДР «Трансдисциплінарна інтелектуальна інформаційно-аналітична система супроводження процесів реабілітації при пандемії,, iї розробки впроваджено до навчально -освітних програмах циклів тематичного удосконалення та спеціалізації лікарів кафедри фізичної та реабілітаційної медицини і спортивної медицини НУОЗ України імені П.Л.Шупика з можливістю їхнього тиражування в інших закладах вищої медичної освіти України

Отримані результати впровадження НДР TISP у навчально-методичні та освітні програми навчання лікарів ФРМ дають підставу рекомендувати впровадження цих навчальних елементів у відповідні програми навчання споріднених кафедр вищих медичних навчальних закладів України.

Необхідно продовжити науково-практичні розробки щодо:

- розширення функціональності системи, зокрема методів і засобів перетворення пасивних знань, закладених у вихідних документах, інструкціях і публікаціях, в активні сервіси

- використання досвіду, накопиченого упродовж боротьби з COVID-19, зокрема висока доцільність широкомасштабних розробки і скорішого впровадження методик і засобів телереабілітації.

Ключові слова: реабілітація, фізична та реабілітаційна медицина, трансдисциплінарна інтелектуальна інформаційноаналітична система супроводження процесів реабілітації, пандемії, . Міжнародна класифікація функиіонування, обмежень життедіяльності та здоров'я, COVID -19.

Вступ. Аналіз стану галузі реабілітації у сфері охорони здоров'я в Україні. Інформаційноаналітична підтримка системи реабілітації в галузі охорони здоров'я орієнтована на реалізацію стратегії реабілітаційних заходів, яка полягає в комплектності та врахуванні патогенетичних особливостей розвитку захворювання. Вона включає: формулювання реабілітаційної мети, яка базується на реабілітаційному едіагнозі; розробку прогнозу; допомогу 3 медичної реабілітації; оцінку ефективності реабілітаційних заходів; реалізацію мультидисциплінарного підходу міждисциплінарними реабілітаційними командами (МРК) до здійснення реабілітаційних заходів [1]. 
Основна стратегія реабілітації у сфері охорони здоров'я:

- діагностує стани здоров'я;

- оцінює функціонування відносно до станів здоров'я, особистих факторів та факторів середовища;

- виконує, застосовує та/або призначає біомедичні та технологічні втручання для лікування станів здоров'я;

- очолює та координує програми втручання для оптимізації активності та участі;

- надає поради пацієнтам та їх найближчому соціальному середовищу, постачальникам послуг та платникам;

- забезпечує освіту пацієнтів, родичів та інших важливих осіб для промоутування функціонування та здоров'я;

- управляє реабілітацією та охороною здоров'я у всіх сферах послуг охорони здоров'я;

- інформує та консультує громадськість та осіб, що ухвалюють рішення, щодо відповідної політики та програм у секторі охорони здоров'я та інших секторах. [1].

Для ФРМ є специфічним поєднання лікувальної і реабілітаційної стратегій шляхом застосування множинних інтервенцій, спрямованих як на лікування патології, так і на подолання обмежень життєдіяльності.

Ініціатива ВООЗ «Реабілітація 2030: заклик до дій» [2] має на меті звернути увагу на зростаючі незадоволені потреби в реабілітації у світі, підкреслити роль реабілітації у досягненні цілей сталого розвитку, запропонованих ООН та закликати до скоординованих й узгоджених глобальних дій щодо посилення реабілітації в системах охорони здоров'я. Загальним для досягнення цих цілей $є$ необхідність навчання лікарів фізичної та реабілітаційної медицини, фізичних терапевтів, ерготерапевтів, інших фахівців з реабілітації та підвищення якості реабілітаційної допомоги.

За поновленим визначенням ВООЗ реабілітацією $\epsilon$ «набір втручань, спрямованих на оптимізацію функціонування та зменшення обмежень життєдіяльності у осіб зі станами здоров'я у взаємодії 3 середовищем» [2]. Це повністю відповідає біопсихо-соціальній моделі обмеження життєдіяльності (моделі, альтернативної до біомедичної моделі), яка розглядає здоров'я та хворобу, як стан обумовлений динамічною взаємодію між біологічними, психологічними та соціальними чинниками. На даній моделі базується Міжнародна класифікація функціонування, обмежень життєдіяльності та здоров'я (МКФ) [3]. МКФ входить до «сімейства» класифікацій, розроблених $\mathrm{BOO} 3$ разом із Міжнародною статистичною класифікацією хвороб та споріднених проблем охорони здоров'я (MКX, International Classification of Diseases), якою історично користується сфера охорони здоров'я у всьому світі та Міжнародною класифікацією втручань в охороні здоров' я (International Classification of Health
Interventions, ICHI) [4], яка дотепер розробляється BOO3. Після оприлюднення ICHI та імплементації усіх трьох міжнародних класифікацій буде можливим повний опис та класифікування будь-яких подій та процесів, які відбуваються у сфері охорони здоров'я, починаючи із причини порушень здоров'я (хвороба, травма тощо - МКХ), будь-яких порушень функціонування / обмежень життєдіяльності (МКФ) та закінчуючи медичними втручаннями, які потребує особа для профілактики та лікування станів здоров'я (профілактична та лікувальна стратегії охорони здоров'я) та реабілітаційними втручаннями, які потребує особа для відновлення та / або компенсації обмежень життєдіяльності (реабілітаційна та підтримуюча стратегії охорони здоров'я).

Відтак, сучасна реабілітація має за мету забезпечити оптимальне функціонування особи зі станами здоров'я в ії середовищі шляхом відновлення функціональних порушень особи (зміни з боку особи) та / або шляхом компенсації цих порушень у разі їх незворотності (зміни з боку середовища). [5] Тож загальними принципами проведення реабілітації є:

- nачієнтоиентричність, що передбачає планування та проведення реабілітації з урахуванням потреб, можливостей та побажань особи, якій надається реабілітаційна допомога або ії законного представника та також членів іiі сім’ї, а також безпосередню їхню участь у розробленні, реалізації та внесенні змін до індивідуального реабілітаційного плану;

- иілеспрямованість - організація процесу реабілітації має бути спрямована на досягнення довгота короткострокових завдань;

- своєчасність - реабілітація має розпочинатися в гострому реабілітаційному періоді або одразу після стабілізації стану здоров'я 3 хронічним перебігом, індивідуальний реабілітаційний план має змінюватися відповідно до зміни функціонального стану особи, якій надається реабілітаційна допомога;

- послідовність - кожний наступний етап процесу реабілітації має бути пов'язаний з попереднім етапом, бути підгрунтям для наступного етапу та враховувати фактичні зміни функціонального стану особи, якій надається реабілітаційна допомога;

- безперервність - процес реабілітації має відбуватися безперервно протягом всіх реабілітаційних періодів;

- функиіональна спрямованість - реабілітаційна допомога має бути спрямована на досягнення оптимального рівня функціонування та якості життя особи у іï середовищі. [1]

Слід також відзначити загальні принщипи реабілітації під час панпідемії:

- неперервність реабілітації;

- розділення команд (кожен співробітник підгрупи не вступає у фізичний контакт с ким-небудь із персоналу іншої підгрупи, щоб мінімізувати ризик перехресної інфекції);

- обмежене пересування персоналу і пацієнтів по 
відділенням і лікарні;

- організація роботи дома;

- розділення пацієнтів на групи ризику при надходженні в стаціонар. [6]

Здійснення вищезазначеного потребує залучення міждисциплінарної реабілітаційної команди (МРК), що складається 3 фахівців 3 реабілітації $[7,8]$, які забезпечують реалізацію відновлювального та / або компенсаторного напрямків реабілітації. Сучасні підходи до надання реабілітаційної допомоги потребують наявності та доступності фахівців 3 реабілітації за наступними основними реабілітаційними професіями [7,9]:

- лікар фізичної та реабілітаційної медицини єдина лікарська спеціальність, яка відповідає за надання реабілітаційної допомоги в розвинених країнах світу;

- фізичний терапевт - нелікарська реабілітаційна професія (вища освіта в сфері охорони здоров'я), що відповідає за забезпечення розвитку, максимального відновлення та підтримання рухової і функціональної спроможності осіб з обмеженнями повсякденного функціонування / обмеженням життєдіяльності, або таких, у яких можуть виникнути такі обмеження;

- ерготерапевт - нелікарська реабілітаційна професія (вища освіта в сфері охорони здоров'я), що відповідає за відновлення, розвиток та / або підтримку навичок, необхідних для залучення особи 3 обмеженням повсякденного функціонування / обмеженням життєдіяльності до активного повсякденного життя та занять, які вона бажає, потребує або планує виконувати, а також модифікація заняттєвої активності особи та / або адаптації іiі середовища;

- терапевт мови та мовлення - нелікарська реабілітаційна професія (вища освіта в сфері охорони здоров'я), що відповідає за відновлення та / або підтримки максимально можливого рівня усіх аспектів комунікації та / або ковтання в осіб 3 обмеженням повсякденного функціонування, або ризиком їх виникнення, для забезпечення оптимального рівня комунікативної взаємодії 3 навколишнім середовищем та / або безпечного процесу споживання їжі.

\section{Наявність базових методичних матеріалів для розробки системи TISP}

Впродовж 2016-2021років в нормативному полі України відбулись зміни, які насамперед стосувались введення нових реабілітаційних професій та формування нормативного підгрунтя для впровадження МКФ:

- введено професійні назви робіт «Лікар фізичної та реабілітаційної медицини» (лікар ФРМ), «Фізичний терапевт» та «Ерготерапевт» до Національного класифікатора України «Класифікатор професій ДК 003 2010» (Наказ Мінекономрозвитку України від 10.08.2016 №1328 «Про затвердження
Зміни №5 до Національного класифікатора України ДК003:2010» [10]), професійних назв робіт «Асистент фізичного терапевта» та «Асистент ерготерапевта» (Наказ Мінекономрозвитку України від 26.10.2017 №1542 «Про затвердження Зміни №6 до Національного класифікатора України ДК003:2010» [11]);

- введення освітньої спеціальності «227 Фізична терапія, ерготерапія» в галузь знань «22 Охорона здоров’ я» (Постанова КМУ від 01.02.2017 № 53 [12]);

план заходів із впровадження в Україні Міжнародної класифікації функціонування, обмежень життєдіяльності та здоров'я (МКФ) та Міжнародної класифікації функціонування, обмежень життєдіяльності та здоров'я дітей і підлітків (МКФДП) (Розпорядження КМУ від 27.12.2017 № 1008$\mathrm{p}[14])$;

- затвердження спеціалізацій «227.01 Фізична терапія» та «227.02 Ерготерапія» в «Переліку спеціалізацій підготовки здобувачів вищої освіти ступеня магістра за спеціальністю «227 Фізична терапія, ерготерапія»») (Наказ MO3 України від 02.11.2018 №2013 [13]);

- затвердження Кваліфікаційних характеристик для повного складу фахівців 3 реабілітації, зокрема «лікар фізичної та реабілітаційної медицини», «фізичний терапевт», «ерготерапевт», «асистент фізичного терапевта», «асистент ерготерапевта» (Наказ МО3 України від 13.12.2018 №2331 [15]);

- внесення лікаря фізичної та реабілітаційної медицини до Номенклатури лікарських спеціальностей (Наказ МОЗ України від 22.02.2019 №446 [16,17]);

- створення в закладах охорони здоров'я лікарської посади «Лікар фізичної та реабілітаційної медицини», посад «Фізичний терапевт», «Ерготерапевт», «Асистент фізичного терапевта», «Асистент ерготерапевта» (зміни до Наказу МО3 України від 28.10.2002 № 385 [18]);

переклад МКФ та МКФ-ДП (Накази МОЗ України від 23.05.2018 №981 та від 21.12.2018 № 2449 [19, 20]) - переклади версії МКФ від 2001 (останнє поновлення - 2018), версії не проведені відповідно до офіційних процедур ВООЗ, термінологія не узгоджена $з$ професійними спільнотами;

- затвердження вторинної спеціалізації з фізичної та реабілітаційної медицини для проведення перенавчання існуючих лікарів у лікарів фізичної та реабілітаційної медицини та зупинка спеціалізації нових лікарів-фізіотерапевтів, лікарів лікувальної фізкультури, лікарів лікувальної фізкультури та спортивної медицини (Наказ МОЗ України від 13.12.2018 № 2332 [21]);

- розробка та затвердження Стандарту вищої освіти України: перший (бакалаврський) рівень, галузь знань «22 Охорона здоров’я», спеціальність «227 Фізична терапія, ерготерапія» (Наказ Міністерства освіти і науки України від 19.12.2018p. № 1419 [22]); 
- отримання першої ліцензії на провадження медичної послуги 3 фізичної та реабілітаційної медицини в Україні (Наказ МО3 України від 12.07.2019 № 1614 [23]);

- затвердження первинної спеціалізації (інтернатури) $з$ фізичної та реабілітаційної медицини для первинної підготовки лікарів фізичної та реабілітаційної медицини (зміни до Наказу МO3 України від 13.12.2018 № 81 [68]).

Прийнятий та набрав чинності закон України «Про реабілітацію у сфері охорони здоров'я» документ 1053-IX, прийнятий 03.12.2020 p., чинний 3 31.12.2020 p.[1 ]

На виконання Закону, підготовлено та узгодженний усіма зацікавленими інституціями і станом на 01 листопада 2021 проходить устаточне корегування в апараті КМУ Проект Постанови КМУ «Питання організації реабілітації у сфері охорони здоров'я», в якому надзвичайно важливими, стосовно виконання нашої роботи, $є$ наступні положення:

Порядок організації надання реабілітаційної допомоги.

Положення про індивідуальний реабілітаційний план, порядок його фінансування та реалізації (ч. 1, ст. 23 Закону).

Типове положення про реабілітаційне відділення, підрозділ.

Типове положення про мультидисциплінарну реабілітаційну команду.

Державний типовий план реабілітації (ч. 2, ст. 24 Закону).

Порядок забезпечення осіб, які потребують реабілітації, технічними та іншими засобами реабілітації (ч. 4, ст. 4 Закону).

Порядок формування та ведення інформаційної системи у сфері реабілітації (ч. 5, ст. 29 Закону).

Порядок надання реабілітаційної допомоги із застосуванням телереабілітації (ч. 4, ст. 19 Закону).

Наказ МО3 України від 18.08.21p. №1753 «Про внесення змін до наказуМО3 України від 22 лютого 2019 №446» - уточнює деякі питання безперервного професійного розвитку лікарів, включено у Номенклатуру лікарських спеціальностей за № 124 «Фізична та реабілітаційна медицина».[24 ]

Наказ Міністерства економіки України від 25 жовтня 2021 № 810-21 « Про затвердження Зміни 10 до національного класифікатора ДК 003:201» введена професія «терапевт мови і мовлення» (У 2229.2) [25]

Набрав чинності наказ МО3 України № 771 від 20.04.2021 p. «Про затвердження Протоколу надання реабілітаційної допомогипацієнтам зкоронавірусною хворобою (COVID-19) та реконвалесцентам».[6] У цьому документі, що прирівнюється до Стандарту надання реабілітаційної допомоги, окресленні наступні системні положення:

- проведення реабілітації у гострий, після гострий та довготривалий періоди реабілітації хворих на
COVID-19 (настанови, практичні тренінги тощо);

- регламентується проведення організації процесу реабілітації хворих дистанційно;

- навчання (навчально методичні рекомендації) лікарів циклів тематичного удосконалення i спеціалізації з ФРМ як з теоретичних питань, так i оволодіння практичними навичками програми ФРМ у дистанційному форматі;

- запровадження телереабілітації у закладах охорони здоров'я, закладах соціальної сфери та громадах.

\section{Особливості політики реабілітації при пандемії. Основні напрямки і задачі}

Пандемія коронавірусної хвороби 2019 (COVID-19), спричинена SARS-CoV-2, суттєвим чином вплинула на традиційні способи та моделі надання реабілітаційної допомоги насамперед через загальне катастрофічне перевантаження системи охорони здоров'я постраждалими від гострої хвороби, що спричинило необхідність швидкого перепрофілювання ліжкового фонду та реорганізації залучення кадрового ресурсу до надання гострої медичної допомоги. 3 іншого боку перша хвиля пандемії (та зараз друга хвиля) негативно вплинула на надання реабілітаційної допомоги впродовж підгострого та довготривалого реабілітаційних періодів.

Реабілітаційний підрозділ Кокранівської бібліотеки, Кокран реабілітація (Cochrane Rehabilitation [26]) з початком пандемії започаткував проєкт REH-COVER (Rehabilitation - COVID-19 Evidence-based Response) [27], в рамках якого здійснюється щомісячне збирання інформації зі всього світу щодо різних аспектів надання реабілітаційної допомоги при пандемії, зокрема для пацієнтів 3 коронавірусною хворобою 2019. Ця інформація представлена у двох форматах:

- інтерактивної мапи, яке відновлює всю інформацію відповідно до дослідницьких тем COVID-19, узгоджених із програмою реабілітації BOO3;

- географічної мапи, на якій видно, де було отримано відповідну доказову інформацію [27].

Підходи щодо надання реабілітаційної допомоги в умовах пандемії, з урахуванням наявного досвіду та наукових публікацій свідчать про значну потребу в організації гострої реабілітаційної допомоги пацієнтам 3 коронавірусною інфекцією, необхідності забезпечення реабілітаційної допомоги для цих паціснтів в підгострому реабілітаційному періоду. Водночас внаслідок пандемії суттєво страждає надання реабілітаційної допомоги пацієнтам, які традиційно іiі потребують. Відтак на перший план виходить гостра необхідність запровадження засобів та технологій телереабілітації для подолання негативних тенденцій, які виникли внаслідок пандемії.

Перша, друга та третя, що триває 3 кінця 
жовтня 2021p., хвилі пандемії негативно вплинули на надання реабілітаційної допомоги впродовж гострого, a особливо, підгострого та довготривалого реабілітаційних періодів. Ми повинні переформатовувати надання реабілітаційної допомоги хворим, підготовку кадрів для реабілітації з урахуванням тенденції довготривалості цієї пандемії та можливих наступних пандемій. Водночас, внаслідок пандемії суттєво страждає надання реабілітаційної допомоги пацієнтам, які традиційно їі потребують. На перший план виходить гостра необхідність запровадження засобів та технологій телереабілітації для подолання негативних тенденцій, які виникли внаслідок пандемії. Тому, надзвичайно актуальною $\epsilon$ виконання та впровадження у практику результатів НДР «Трансдисциплінарна інтелектуальна інформаційно-аналітична система супроводження процесів реабілітації при пандемії».

Виходячи iз вищезазначеного, Вченою радою Національного університету охорони здоров'я України імені П. Л. Шупика (протокол № 8 від 21.05.2021 р.) затверджені:

Навчальний план та програма циклу тематичного удосконалення «Фізична та реабілітаційна медицина хворих на COVID-19 та осіб з наслідками коронавірусної інфекції» (тривалість навчання - 0,5 місяця (78 годин)).

Навчальна програма циклу тематичного удосконалення «Фізична та реабілітаційна медицина хворих на COVID-19 та осіб 3 наслідками коронавірусної інфекції» призначена для підвищення кваліфікації лікарів: 3 фізичної та реабілітаційної медицини (ФРМ), спортивної медицини, фізіотерапевтів, лікувальної фізкультури, хірургів, з функціональної діагностики, кардіологів, ревматологів, педіатрів, терапевтів, лікарів загальної практики-сімейної медицини, керівників закладів охорони здоров'я.

Метою навчання на циклі «Фізична та реабілітаційна медицина хворих на COVID-19 та осіб 3 наслідками коронавірусної інфекції» $\epsilon$ підвищення рівня знань лікарів вказаних профілів 3 питань фізичної та реабілітаційної медицини при патологічних станах спричинених коронавірусом $S A R S-C o V-2$. Удосконалення теоретичних знань та практичної підготовки, формування, оновлення, поглиблення ключових професійних компетенцій, а також отримання нових актуальних знань 3 ФРМ, необхідних для професійної діяльності слухачів відповідно до вимог системи якості підготовки кадрів для сфери охорони здоров'я, ознайомлення 3 новітніми досягненнями тощо.

Матеріали циклу направлені на засвоєння лікарями навичок реабілітаційної допомоги при захворюванні COVID-19, починаючи 3 гострого періоду і закінчуючи від 2 до 6 місяців після одужання - залежно від тяжкості перебігу хвороби.

Фізична та реабілітаційна допомога реалізується, як в умовах стаціонару: відділеннях ВРIT, клінічних відділеннях, денних стаціонарах, спеціалізованих iз лікування та реабілітації COVID-19, так і при амбулаторній допомозі: в амбулаторіях загальної практики-сімейної медицини, домашніх умовах на підставі означених критеріїв реабілітаційної діагностики та контролю, за відповідними алгоритмами, із забезпеченням профілактики інфікування персоналу та передачі вірусу інфікованими на SARS-CoV-2 або пацієнтами, у яких підозрюється діагноз COVID-19, або пацієнтами, у яких не можна виключити діагноз COVID-19.

Зміст програми охоплює базовий обсяг сучасних теоретичних знань i практичних навичок цієї галузі. Значний акцент зроблено на ролі лікаря ФРМ, фізичного терапевта та ерготерапевта в мультидисциплінарній команді при проведенні реабілітаційних заходів у хворих на COVID-19 та осіб з наслідками коронавірусної інфекції.

Програма складається 37 розділів.

Перший розділ включає загальні уявлення про фізичну та реабілітаційну медицину (ФРМ). Розглядаються функції мультидисциплінарної команди та кваліфікаційні вимоги лікаря ФРМ. Також у розділі представлено основи міжнародної класифікації функціонування, обмеження життєдіяльності та здоров'я: теоретичні аспекти та практичне їх застосування.

Другий розділ вивчає новий коронавірус SARSCoV-2, який з'явився у 2019 році та викликав пандемію. Розглядаються клінічні форми COVID-19: безсимптомний перебіг, синдром гострого респіраторного дистресу (СГРД), септичний (інфекційно-токсичний) шок, вплив SARS-CoV-2 на серцево-судинну систему, вплив SARS-CoV-2 на нервову систему, Post-COVID-синдром, PostCOVID long-hauler - стан порушення рівня здоров'я й функціонування через 6 місяців після перенесеного захворювання, спричиненого SARS-CoV-2.

Третій розділ розглядає задачі гострої реабілітації, протиепідемічні вимоги для реабілітаційного втручання, реабілітаційну діагностику, предиктори початку реабілітаційного втручання при наявності показань, предиктори протипоказань і припинення реабілітаційного втручання. А також позиціонування при відлученні від ШВЛ та методи очищення дихальних шляхів. Вивчаються мануальні методи, дихальні вправи, мобілізація, психотерапія, апаратна медицина та логопедична допомога.

Четвертий розділ присвячений післягострій реабілітації, менеджменту фізичної терапії, інтервальному тренуванню аеробних та анаеробних механізмів енергозабезпечення, апаратній медицині. Також висвітлюються питання ерготерапії, психотерапії. Приділено увагу методам контролю ефективності реабілітації на підгострому етапі реабілітації.

У n'ятому розділі розглянуті загальні задачі довготривалої реабілітації; показання для 
респіраторної реабілітації; застереження для амбулаторної реабілітації 3 боку стану пацієнта - ускладнення інфекції SARS-CoV-2; методи діагностики та діагностичні показники, що актуальні для складання індивідуальної програми реабілітації; контроль ефективності довготривалого реабілітаційного втручання.

Шостий розділ присвячений кардіопульмональному тестуванню 3 навантаженням. Розглядаються протипоказання для проведення фізичних навантажень, терміновий (експрес) контроль в процесі заняття, стоп-знаки. Вивчаються I етап прогресивного тренування, ІІ етап прогресивного тренування, критерії поточного контролю.

У сьомому розділі вивчаються клінічні протоколи реабілітації осіб різного контингенту (дорослі пацієнти, люди похилого віку, діти, вагітні жінки) та діагностичні реабілітаційні шкали: Шкала больової поведінки BPS Behavioral Pain Scale; Клініколабораторні критерії діагностики недостатності харчування; Шкала BDI (Baseline Dyspnea Index, вихідний індекс задишки); Шкала задишки mMRC (Modified Medical Research Council); Шкала Комітету медичних досліджень (Medical Research Council, MRC) для оцінки м'язової сил; Бланк для оцінки м'язової сили за Шкалою Комітету медичних досліджень; Шкала Борга; Госпітальна шкала тривоги і депресіï (Hospital Anxiety and Depression Scale, HADS). Вперше нами подається Перелік практичних навичок, якими повинні оволодіти лікарі ФРМ при наданні реабілітаційної допомоги хворим на COVID-19 та осіб з наслідками коронавірусної інфекції.

\section{Підготовка зразків супроводжувальних документів (історія хвороби, виписка паціснтів тощо) для систем TISP}

На сьогодні в Україні у сфері реабілітаційних послуг на етапах гострої, підгострої та довготривалої реабілітації запроваджені наступні форми документообігу:

Індивідуальна реабілітаційна карта пацієнта (нервова система).

Індивідуальний реабілітаційний план 3 фізичної терапії.

Індивідуальна реабілітаційна карта пацієнта (опорно-рухова система).

Індивідуальна реабілітаційна карта пацієнта.

Реабілітаційна карта пацієнта з ураженням ОРА.

Реабілітаційна карта пацієнта 3 ураженням спинного мозку.

Реабілітаційна карта неврологічного пацієнта. Карта хворого, якого скеровано на реабілітацію. Проте, потребує вирішення у підзаконих актах до

Таблиця 1. Перелік практичних навичок циклу «Фізична та реабілітаційна медицина хворих на COVID-19 та осіб з наслідками коронавірусної інфекції» зі спеціальності Фізична та реабілітаційна медицина

\begin{tabular}{|c|c|}
\hline № & Перелік навичок \\
\hline 1 & $\begin{array}{l}\text { Організація протиепідемічних заходів лікарем ФРМ в процесі реабілітації хворих на COVID-19 } \\
\text { в стаціонарі }\end{array}$ \\
\hline 2 & $\begin{array}{l}\text { Визначення прогнозу серцево-судинних ускладнень у пацієнта з COVID-19 та складання } \\
\text { рекомендацій для таких пацієнтів }\end{array}$ \\
\hline 3 & Визначення показань для реабілітаційного втручання за станом пацієнта хворого на COVID-19 \\
\hline 4 & Організація моніторингу стану пацієнта хворого на COVID-19 в стаціонарі лікарем ФРМ \\
\hline 5 & $\begin{array}{l}\text { Визначення часу і характеру початка реабілітаційного втручання для пацієнта хворого на } \\
\text { COVID-19 }\end{array}$ \\
\hline 6 & $\begin{array}{l}\text { Прийняття рішення щодо припинення реабілітаційного втручання в процесі гострої реабілітації } \\
\text { хворого на COVID-19 }\end{array}$ \\
\hline 7 & $\begin{array}{l}\text { Прийняття рішення щодо позиціонування хворого на COVID-19, що знаходиться на ліжковому } \\
\text { режимі }\end{array}$ \\
\hline 8 & Прийняття рішення щодо очищення дихальних шляхів хворого на COVID-19 \\
\hline 9 & Призначення дихальних вправ на етапі гострої реабілітації хворого на COVID-19 \\
\hline 10 & Призначення активної мобілізації хворому на COVID-19 в гострій реабілітації \\
\hline 11 & Прийняття рішення про початок післягострої реабілітації хворим на COVID-19 \\
\hline 12 & Організація моніторингу стану пацієнта хворого на COVID-19 в післягострій реабілітації \\
\hline 13 & Прийняття рішення про припинення реабілітаційного втручання в післягострій реабілітації \\
\hline 14 & Призначення респіраторної реабілітації в післягострій реабілітації хворих на COVID-19 \\
\hline 15 & Призначення вправ для м’язів в післягострій реабілітації хворого на COVID-19 \\
\hline
\end{tabular}


закону «Про реабілітацію у сфері охорони здоров’я» наступні питання щодо реабілітаційної документації:

Стандартизація реабілітаційних планів відповідно до пакетів реабілітаційних послуг, що сплачуються Національною службою здоров'я України(НСЗУ) у нозологіях неврологія, ОРА, раннє втручання, 3 педіатричною специфікою, пульмонологія та ін.

- Правила сортування пацієнтів, що підлягають реабілітаційній допомозі чи паліативному догляду.

- Покази, протипокази до реабілітаційного втручання відповідно до нозологій (неврологія, ОРА, ССС, дихальна система та ін.).

- Статистична форма звітності щодо реабілітаційного лікування (наприклад, типу Ф-№ 20 «Звіт лікувально-профілактичного закладу за 20 рік») для планування бюджету на наступний рік.

- Перелік основних, валідованих, офіційно затверджених оціночних інструментів відповідно до нозологій (реабілітаційних пакетів).

- Перелік коректних кодів за МКХ-10 чи вже MKX-11, що відповідатимуть реабілітаційним епізодам відповідно до пакетів.

- Роз'яснення щодо довготривалої реабілітації (на поліклінічному рівні) - мінімальна кількість членів реабілітаційної команди, вимоги до обладнання, правила оплати за надані послуги.

Необхідний чіткий алгоритм надання реабілітаційної допомоги (реабілітаційні протоколи або роз'яснення, якими протоколами можемо користуватися на даний момент).

\section{Оволодіння викладачами практичних навичок у викладанні системи TISP, підготовка навчально-методичних матеріалів для здійснення навчального процесу, використання підсистем телереабілітації TISP}

Дуже важливим в процесі роботи над проєктом була організація взаємодії між розробниками інформаційно-аналітичної системи і спеціалістами реабілітологами. В центрі уваги була Міжнародна Класифікація Функціональностей та їі застосування в практичній діяльності реабілітаційної команди.

Інтерактивною базою знань, що створено у форматі онтологічної системи за методами та засобами, які викладено у НДР: «Трансдисциплінарна інтелектуальна інформаційно-аналітична система супроводження процесів реабілітації при пандемії» є онтологічний кабінет лікаря фізичної та реабілітаційної медицини (ФРМ). Напрацьовані функціональні вимоги до робочого місця лікаря, що входить до міждисциплінарного колективу лікарів, які забезпечують процес реабілітації. 3 точки зору суті проєкту, тобто галузі реабілітації, специфічним модулем $\epsilon$ саме модуль «Робоче місце лікаря спеціалізованої медичної допомоги», бо реабілітація не входить в склад ПМД. Вимоги до такого модуля в складі МІС до роботи з ЕМЗ включають:
1. Вимоги до пакету даних діагностичного звіту.

2. Вимоги до процедур.

3. Вимоги до ЕМЗ та ЕН для неідентифікованих пацієнтів.

4. Вимоги до виписування ЕН.

5. Вимоги до функціоналу перевірки та взяття в обробку ЕН НМП.

6. Вимоги до погашення ЕН лікарем СМД.

7. Вимоги до ведення ЕМЗ в стаціонарних умовах надання медичних послуг:

- вимоги до ведення ЕМЗ при надходженні пацієнта до НМП СМД;

- вимоги до ведення ЕМЗ при виписці пацієнта 3 НМП СМД.

Вказаний кабінет забезпечує онтолого-керовану операціональність взаємодії лікаря ФРМ і пацієнта.

Онтологічний кабінет кожного лікаря ФРМ формується на основі таксономії «Білої Книги фізичної та реабілітаційної медицини у Європі» (БК)), яка є довідником для лікарів ФРМ у Європі. Таксономічна структура БК фактично представляє усю ієрархію регламентів, правил та послуг, які повинен надавати лікар ФРМ. БК відображає класифікацію операціонального поля діяльності лікаря ФРМ, яке включає певні кваліфікатори, що позначає величину рівня здоров'я, набір певних впливів та дій по відношенню до пацієнта тощо. Вибір конкретних дій відносно пацієнта регулюється шкалами оцінки його стану. Перевагою онтологокерованого підходу до забезпечення діяльності лікаря ФРМ є автоматичний вибір набору дій, оперативне отримання необхідних методичних матеріалів, постійний моніторинг за станом пацієнта.

Підготовка курсу викладання системи TISP y навчальні цикли спеціалізації та удосконалення лікарів ФРМ в НУОЗ України імені

\section{П. Л. Шупика}

3 17.06.2021p. відбуваються щомісячні онлайн семінар-тренінги 3 впровадження системи TISP«Трансдисциплінарна інтелектуальна інформаційно-аналітична система супроводження процесів реабілітації при пандемії» за участі спеціалістів Інституту кібернетики імені В.М.Глушкова НАН України.

У навчанні прийняли участь 13 викладачів кафедри ФРМ і СМ та понад 120 лікарів 3 усіх регіонів України, що навчаються на циклі спеціалізації 3 ФРМ. Це перші реальні кроки впровадження в навчальні програми та у практичну діяльність лікарів ФРМ елементів системи TISP, телемедицини i телереабілітації. Отримані практичні навички та досвід дають підставу рекомендувати впровадження цих навчальних елементів у відповідні програми навчання споріднених кафедр вищих медичних навчальних закладів України.

Колективом кафедри фізиччної та реабілітаційної медицини і спортивної медицини НУОЗ України імені П. Л. Шупика Підготовлений до друку навчально- 
методичний посібник «Міжнародна класифікація функціонування, обмеження життєдіяльності та здоров'я (МКФ) - впровадження у медичну практику на Україні» (затверджений до друку вченою радою НУОЗ України, Протокол №10 від 16.06.2021 р.). У навчально-методичному посібнику вже знайшли відображення положення НДР: «Трансдисциплінарна інтелектуальна інформаційноаналітична система супроводження процесів реабілітації при пандемії», а саме: представлення міжнародної класифікації функціонування, обмежень життєдіяльності та здоров'я у TISP - отримано файл $\mathrm{xml}$ формату, який містить структуровану МКФ українською мовою. Відображення змісту файлу здійснюється за допомогою стандартного модуля відображення онтологій TISP, Стандартний модуль відображення онтологій містить наступні режими: об'єктного відображення, табличного відображення, відображення онтографа.

Особливістю та позитивом, щодо практичного використання доробок НДР «Трансдисциплінарна інтелектуальна інформаційно-аналітична система супроводження процесів реабілітації при пандемії» $€$ можливість опанування постулатів «Білої Книги», біопсихосоціальної моделі реабілітації, що базується на доменах Міжнародної класифікації обмеження життєдіяльності та здоров'я, вивчення цієї класифікації, іiі впровадження у практичну реабілітаційну діяльність на підставі трансдисциплінарної інтелектуальної інформаційноаналітичної системи супроводження процесів реабілітації, що надзвичайно актуально у теперішній ситуації при пандемії Covid -19.

Одне із завдань розбудови ФРМ в Україні, що вирішується у НДР: «Трансдисциплінарна інтелектуальна інформаційно-аналітична система супроводження процесів реабілітації при пандемії» використання сучасних методів штучного інтелекту та інтелектуальних інформаційних технологій, які не мають аналогів у реабілітаційній сфері інших країн.

На даному етапі виконання роботи (вересень - грудень 2021р.) вирішуються дві складові НДР: практична - на рівні відносин реабілітолог-пацієнт та навчально-методична, що сфокусована на створенні та удосконаленні методів і засобів підвищення викладання теоретичних i практичних освітніх питань дисципліни «Фізична та реабілітаційна медицина» згідно світових стандартів, розробки i супроводження методології реабілітаційних заходів та оцінки їх ефективності.

В подальшому доцільно зосередити увагу i ресурси на де кількох головних напрямках.

Перший напрямок стосується розширення функціональності системи, зокрема методів і засобів перетворення пасивних знань, закладених у вихідних документах, інструкціях і публікаціях, в активні сервіси.

Другий напрямок - використання досвіду, накопиченого в ході боротьби з COVID-19, зокрема висока доцільність широкомасштабних розробки i скорішого впровадження методик i засобів телереабілітації, які окрім прямого призначення виконують ще й профілактичні функції.

Tретій напрямок пов'язаний 3 унікальною можливістю застосувати останні напрацювання Інституту кібернетики 3 інтелектуальної інформаційної підтримки наукових досліджень 3 орієнтацією на медично-реабілітаційну галузь (створення персональних баз знань, патентної діяльності тощо).

Враховуючи позитивні, вже отримані, результати НДР «Трансдисциплінарна інтелектуальна інформаційно-аналітична система супроводження процесів реабілітації при пандемії», їх актуальність в ситуації глобального розповсюдження пандемиї Covid -19, - прийнято рішення доповісти результати дослідження на окремому сесійному засіданні 3 практичним воркшопом на II-му Національному Конгресі Фізичної та Реабілітаційної медииини «Фізична та реабілітаційна медицина в Україні: підготовка кадрів мультипрофесійної команди, організація реабілітаційного процесу в закладах охорони здоров'я», що відбудеться в он-лайн форматі 15-16 грудня 2021 р. у м. Києві.

\section{Список літератури}

1. Про реабілітацію в сфері здоров'я: Закон України “ Про реабілітацію в сфері охорони здоровья», Available from: https://zakon.rada.gov.ua/laws/show/105320\#Text.

2. Rehabilitation 2030: A Call for Action(https://www.who. int/disabilities/care/Rehab2030MeetingReport_plain_text_ version.pdf)

3. International Classification of Functioning, Disability and Health (ICF) [Internet]. World Health Organization. 2019 [cited 9 March 2019]. Available from:

https://www.who.int/classifications/icf/en/

4. International Classification of Health Interventions (ICHI) [Internet]. World Health Organization. 2020 [cited 22 November 2020]. Available from: https://www.who. int/classifications/international-classification-of-healthinterventions

5. Альянс Європейських органів Фізичної та Реабілітаційної Медицини. Біла Книга з Фізичної та Реабілітаційної Медицини (ФРМ) в Європі. Український журнал фізичної

та реабілітаційної медицини. 2018; 2 (2). С. 5-206

6. Про затвердження Протоколу надання реабілітаційної допомоги пацієнтам 3 короновірусною хворобою(COVID -19) та реконвалесцентам: Наказ

Міністерства охорони здоров'я України від 20.04.2021 року № 771, Available from:

http://search.ligazakon.ua/1_doc2.nsf/link1/RE36960.html

7. European Physical and Rehabilitation Medicine Bodies Alliance. White Book on Physical

and Rehabilitation Medicine in Europe. Eur J Phys Rehabil Med. 2018; 54: 125-321. 
8. Gutenbrunner C, Tederko P, Grabljevec K, Nugraha B. Responding to the World Health

Organization Global Disability Action Plan in Ukraine: Developing a National Disability,

Health and Rehabilitation Plan. J Rehabil Med 2018; 50: 338-341.

9. Про активізацію роботи щодо забезпечення прав людей з інвалідністю: Указ

Президента України від 03.12.2015 №678/2015 [cited 2020 June 30] Available from: https://www.president.gov. ua/documents/6782015-19605

10. Про затвердження Зміни №5 до Національного класифікатора України ДК 003:2010:

Наказ Мінекономрозвитку України від 10.08.2016 №1328 [cited 22 November 2020]. Available from: https:// zakon.rada.gov.ua/rada/show/v1328731-16\#n2

11. Про затвердження Зміни №6 до Національного класифікатора України ДК 003:2010: Наказ Мінекономрозвитку України від 26.10.2017 №1542 [cited 22 November 2020]. Available from: https://zakon. rada.gov.ua/rada/show/v1542731-17\#n9

12. Введення освітньої спеціальності «227 Фізична терапія, ерготерапія» в галузь знань «22 Охорона здоров'я» (Постанова КМУ від 01.02.2017 № 53 [12]);

13. Про затвердження Переліку спеціалізацій підготовки здобувачів вищої освіти ступеня магістра за спеціальністю 227 «Фізична терапія, ерготерапія».: Наказ Міністерства охорони здоровя України від 02.11.2018 №2013 [cited 2020 June Available from: https://zakon.rada.gov.ua/laws/show/z1335-18

14. Про затвердження плану заходів із впровадження в Україні Міжнародної класифікації функціонування, обмежень життєдіяльності та здоров'я та Міжнародної класифікаціїфункціонування, обмеженьжиттєдіяльності та здоров'я дітей і підлітків.: Розпорядження Кабінету Міністрів України від 27.12.2017 №1008-p [cited 2020 June 30] Available from: https://zakon.rada.gov.ua/laws/ show $/ 1008-2017-\%$ D $1 \% 80$

15. Про внесення змін до Довідника кваліфікаційних характеристик професій працівників. Випуск 78 «Охорона здоров'я»: Наказ Міністерства охорони здоров’я України від 13.12.2018 №2231 [cited 2020 June 30]. Available from: https://zakon.rada.gov.ua/rada/show/ v2331282-18

16. Деякі питання безперервного професійного розвитку лікарів: Наказ Міністерств охорони здоровя України від 22.02.2019 №446 [cited 2020 June 30] Available from: https://zakon.rada.gov.ua/laws/show/z0293-19

17. Номенклатура лікарських спеціальностей: Затверджено Наказом Міністерства охорони здоров'я України від 22.02.2019 №446 [cited 2020 June 30] Available from: https://zakon.rada.gov.ua/laws/show/ z0294-1919. Наказ Міністерства охорони здоров'я України від 21.12.2018 №2449 «Про внесення змін до перекладу Міжнародної класифікації функціонування, обмежень життєдіяльності та здоров'я та Міжнародної класифікації функціонування, обмежень життєдіяльності та здоров'я дітей і підлітків» (https:// moz.gov.ua/uploads/1/9898-dn_20181221_2449.pdf)
18. Зміни до Наказу МОЗ України від 28.10.2002 № 385: Наказ Міністерства охорони здоров'я України від 19.04.2019 року № 668, Available from: https://zakon.rada. gov.ua/laws/show/z0417-19\#Text [18]);

19. Наказ Міністерства охорони здоров'я України від 21.12.2018 №2449 «Про внесення змін до перекладу Міжнародної класифікації функціонування, обмежень життєдіяльностітаздоров'ятаМіжнародноїкласифікації функціонування, обмежень життєдіяльності та здоров'я дітей і підлітків» (https://moz.gov.ua/uploads/1/9898dn_20181221_2449.pdf)

20. Наказ Міністерства охорони здоров'я України від 23.05.2018 №981 «Про затвердження перекладу Міжнародної класифікації функціонування, обмежень життєдіяльностітаздоров'я таМіжнародноїкласифікації функціонування, обмежень життєдіяльності та здоров'я дітей і підлітків» (https://moz.gov.ua/article/ministrymandates/nakaz-moz-ukraini-vid-23052018--9

21. Про внесення змін до Переліку назв циклів спеціалізації та вдосконалення лікарів і провізорів у вищих медичних (фармацевтичному) закладах (факультетах) післядипломної освіти: Наказ Міністерства охорони здоровя України від 13.12.2018

№2332 [cited 2020 June 30] Available from: https://zakon.rada.gov.ua/rada/show/v2332282-18\#n2

22. Про затвердження стандарту вищої освіти за спеціальністю 227 «Фізична терапія, ерготерапія» для першого (бакалаврського) рівня вищої освіти: Наказ Міністерства освіти і науки від 19.12.2018 №1419 [cited 2020 June 30] Available from:

https://mon.gov.ua/storage/app/media/vishcha-osvita/ zatverdzeni\%20standarty/12/21/227- fizichna-terapiyaergoterapiya-bakalavr.pdf

23. Про ліцензування медичної практики: Наказ Міністерства охорони здоров'я України від 12.07.2019 №1614 [cited 2020 June 30] Available from:

https://moz.gov.ua/uploads/ckeditor

24. Про внесення змін до наказу Міністерства охорони здоров’я України від 22 лютого 2019 року № 446: Наказ Міністерства охорони здоров'я України від 18.08.2021 року № 1753, Available from:

http://search.ligazakon.ua/l doc2.nsf/link1/RE36960.html

25. Про затвердження Зміни № 10 до національного класифікатора ДК 003:2010: Наказ Міністерства економіки України від 25 жовтня 2021 року № 81021, Available from:https://zakon.rada.gov.ua/rada/show/ v0810930-21\#Text

26. REH-COVER: https://rehabilitation.cochrane.org/ resources/cochrane-rehabilitation-versu covid-19

27. REH-COVER - Interactive living evidence https:// rehabilitation.cochrane.org/covid-19/recover-interactiveliving-evidence

\section{References}

1. On Rehabilitation in the Sphere of Health: Law of Ukraine "On Rehabilitation in the Sphere Healthcare ", Available from: https://zakon.rada.gov.ua/laws/show/105320\#Text.

2. Rehabilitation 2030: A Call For Action (https://www. 
who.int/disabilities/care/Rehab2030Me etingReport_plain_ text_version.pdf )

3. International Classification of Functioning, Disability and Health (ICF) [Internet]. World Health Organization. 2019 [cited 9 March 2019]. Available from: https://www. who.int/classifications/icf/en/

4. International Classification of Health Interventions (ICHI) [Internet]. World Health Organization. 2020 [cited 22 November 2020]. Available from: https://www.who. int/classifications/international-classification-of-healthinterventions

5. Alliance of European Bodies of Physical and Rehabilitation Medicine. White Paper with Physical and Rehabilitation Medicine (FRM) in Europe. Ukrainian Journal of Physical and rehabilitation medicine. 2018; 2 (2). C. 5-206 (in Ukraine )

6. On approval of the Protocol for the provision of rehabilitation care to patients with coronavirus

disease (COVID -19) and convalescents: Order Ministry of Health of Ukraine dated April 20, 2021 № 771, Available from: http://search.ligazakon.ua/1_doc2.nsf/link1/RE36960. $\underline{\mathrm{html}}$ ( in Ukraine )

7. European Physical and Rehabilitation Medicine Bodies Alliance. White Book on Physical and Rehabilitation Medicine in Europe. Eur J Phys Rehabil Med. 2018; 54: 125-321.

8. Gutenbrunner C, Tederko P, Grabljevec K, Nugraha B. Responding to the World Health Organization Global Disability Action Plan in Ukraine: Developing a National Disability, Health and Rehabilitation Plan. J Rehabil Med 2018; 50: 338-3419.

9. On intensifying work ensure the rights of people with disabilities: Decree Of the President of Ukraine dated 03.12.2015 №678 / 2015 [cited 2020 June 30] Available https://www.president.gov.ua/documents/6782015-19605 ( in Ukraine )

10. On approval of Amendment №5 to the National Classification of Ukraine DK 003: 2010: Order of the Ministry of Economic Development of Ukraine dated 10.08.2016 81328 [cited 22 November 2020]. Available from: https://zakon.rada.gov.ua/rada/show/v1328731-

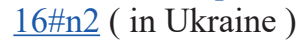

11. On approval of Amendment №6 to the National Classification of Ukraine DK 003: 2010: Order of the Ministry of Economic Development of Ukraine dated

26.10.2017 421542 [cited 22 November 2020]. Available from: https://zakon.rada.gov.ua/rada/show/v1542731$17 \# \mathrm{n} 9$ ( in ukraine ) 12. Introduction of the educational specialty "227 Physical Therapy, Occupational Therapy" in the industry knowledge "22 Health Care" (Resolution of the Cabinet of Ministers of 01.02.2017 № 53 [12]); ( in ukraine )

13. On approval of the List of specializations for higher education Master's degree in 227 "Physical Therapy, Occupational Therapy" .: Order Ministry of Health of Ukraine from 02.11.2018 №2013 [cited 2020 June Available from: https://zakon.rada.gov.ua/laws/show/z1335-18 ( in Ukraine )

14. On approval of the action plan for implementation of the International Classification in Ukraine functioning, limitations of life and health and the International Classification its functioning, restrictions on the life and health of children and adolescents .: Order of the Cabinet of Ministers of Ukraine dated 27.12.2017 №1008-p [cited 2020 June 30] Available from: https://zakon.rada.gov.ua/ laws/show/1008- 2017-\%D1\%80 ( in Ukraine )

15. On amendments to the Handbook of Qualification Characteristics of Professions employees. Issue 78 "Health Care": Order of the Ministry of Health Of Ukraine dated 13.12.2018 312231 [cited 2020 June 30]. Available from: https://zakon.rada.gov.ua/rada/show/v2331282-18 ( in Ukraine )

16. Some issues of continuous professional development of doctors: Order of the Ministries of Health Protection of Ukraine from 22.02.2019 №446 [cited 2020 June 30] Available from: https://zakon.rada.gov.ua/laws/show/ z0293-19 ( ( in Ukraine )

17. Nomenclature of medical specialties: Approved by Order of the Ministry of Health of Ukraine from 22.02.2019 №446 [cited 2020 June 30] Available from:

https://zakon.rada.gov.ua/laws/show/z0294-1919. Order of the Ministry of Health Of Ukraine dated 21.12.2018 №2449 "On Amendments to the International Translation classification of functioning, limitations of life and health and International classification of functioning, limitations of life and health of children and teenagers "(https://moz.gov. ua/uploads/1/9898-dn_20181221_2449.pdf) (in Ukraine )

18. Amendments to the Order of the Ministry of Health of Ukraine dated 28.10.2002 № 385: Order of the Ministry of Protection Health of Ukraine dated April 19, 2019 №

668, Available from: https://zakon.rada.gov.ua/laws/show/ z0417-19\#Text [18]); ( in Ukraine )

19. Order of the Ministry of Health of Ukraine dated 21.12.2018 №2449 “On introduction changes to the translation of the International Classification of Functioning, restrictions life and health and the International Classification of Functioning, Restrictions life and health of children and adolescents “ (https://moz.gov.ua/uploads/1/9898dn_20181221_2449.pdf) ( ( in ukraine )

20. Order of the Ministry of Health of Ukraine dated 23.05.2018 №981 “On approval of the translation of the International Classification of Functions, Restrictions life and health and the International Classification of Functioning, Restrictions life and health of children and adolescents (https://moz.gov.ua/article/ministry- mandates / nakaz-moz-ukraini-vid- 23052018-9 ( ( in ukraine )

21. On amendments to the List of names of cycles of specialization and improvement of doctors and pharmacists in higher medical (pharmaceutical) institutions (faculties) Postgraduate Education: Order of the Ministry of Health of Ukraine dated 13.12.2018 №2332 [cited 2020 June 30] Available from: https://zakon.rada.gov.ua/rada/show/ v2332282-18\#n2 (in Ukraine )

22. On approval of the standard of higher education in the specialty 227 "Physical therapy, occupational therapy "for the first (bachelor's) level of higher education: Order of the Ministry of Education and Science from 19.12.2018 №1419 [cited 2020 June 30] Available from: https://mon. gov.ua/storage/app/media/vishcha-osvita/zatverdzeni\%20 
standarty/12/21/227- fizichna-terapiya-ergoterapiyabakalavr.pdf ( in Ukraine )

23. On licensing of medical practice: Order of the Ministry of Health of Ukraine from 12.07.2019 №1614 [cited 2020 June 30] Available from: https://moz.gov.ua/uploads/ ckeditor (in Ukraine )

24. On amendments to the order of the Ministry of Health of Ukraine of 22 February 2019 № 446: Order of the Ministry of Health of Ukraine from 1853.2021 № 1753, Available from: http://search.ligazakon.ua/l doc2.nsf/link1/RE36960.html ( in Ukraine )

25. On approval of Amendment № 10 to the national classifier DK 003: 2010: Order of the Ministry of Economy of Ukraine of October 25, 2021 № 810-21, Availabl from: https: //zakon.rada.gov.ua/rada/show/v0810930-21\#Text ( in Ukraine )

26. REH-COVER: https://rehabilitation.cochrane.org/ resources/cochrane-rehabilitation-versu covid-19

27. REH-COVER - Interactive living evidence https:// rehabilitation.cochrane.org/covid-19/re cover-interactiveliving-evidence

\title{
NEW ALGORITHMS OF PHYSICAL AND REHABILITATION MEDICINE IN THE AREAS OF EDUCATION AND PRACTICAL ACTIVITIES ON THE BASIS OF IMPLEMENTATION OF THE SYSTEM "TRANSDISCIPLINARY INTELLECTUAL INFORMATION-ANALYTICAL SYSTEM OF SUPPORT OF REHABILITATION PROCESSES DURING PANDEMIC" (TISP)
}

\author{
Vladymyrov O.A., Golyk, V.A.
}

\section{Shupyk National University Healthcare of Ukraine, Department of Physical and Rehabilitation Medicine and Sports Medicine,} Kyiv, Ukraine

A special role in the implementation of all functionalities for the rehabilitation of patients in a large-scale pandemic are: support for information and analytical processes of data collection and processing; classification of patients by health status; investigation of fundamental causes and consequences of crisis (pandemic) situations at country level and worldwide; support for decision-making at all governamce levels, development and correction of general policies for development of the state and specific regions; provision information and advisory support for the population; methodological principles of recovery and rehabilitation in accordance with the recommendations of the White Book of Physical and Rehabilktation Medicine in Europe, which is a key European guide for professionals of all ranks: from physicians to healthcare decision-makers on the state level. In recent years, the development of rehabilitation service and, in particular, Physical and Rehabilitation Medicine (PRM) in Ukraine has gained momentum. This process requires systematization of data collection on disability and planning of rehabilitation services, as well as individual disability assessment and setting rehabilitation goals.

Thus, it is important today to create the Transdisciplinary intelligent information-analytical system to support (including real-time) of rehabilitation processes in pandemics, which solve a range of problems related to improving the effectiveness of combating global natural disasters that threaten human life and sustainable development of society.

Goal mastering the system "Transdisciplinary intellectual information-analytical system of support of rehabilitation processes during pandemic" and implementation of it's developments into the educational training programs of physicians.

Methods and materials were official documents of the World Health Organization, legislative acts in the field of healthcare and rehabilitation of Ukraine, orders of the Cabinet of Ministers of Ukraine, orders of the Ministry of Health of Ukraine and other ministries, "Report of the first stage of research "Transdisciplinary intellectual information-analytical system of support of rehabilitation processes during pandemic" (TISP), NFD of Ukraine for 2020, educational and methodical materials of the Department of Physical and Rehabilitation Medicine and Sports Medicine of the Shupyk NUHCU - by their analysis, systematization, forecasting.

The results of the research "Transdisciplinary intellectual information-analytical system of support of rehabilitation processes during pandemic" (TISP) were processed, implemented into educational programs, thematic training programs and curriculum for physicians specialization at the Department of Physical and Rehabilitation Medicine and Sports Medicine of Shupyk NUHCU with possibility of it replication in other higher medical education institutions in Ukraine

The obtained results of TISP implementation into educational-methodological and educational training programs of PRM physicians are supporting the recommendations for implementation of these training elements into the specific curricula at related departments of higher medical educational institutions in Ukraine.

It is necessary to continue scientific and practical developments on:

- expanding the functionality of the system, in particular methods and means of converting passive knowledge embedded in source documents, instructions and publications, into active services

- use of the experience gained during the fight against COVID-19, in particular the high feasibility of large-scale development and faster implementation of methods and tools of telerehabilitation.

Keywords: rehabilitation, Physical and Rehabilitation Medicine, transdisciplinary intellectual information-analytical system of support of rehabilitation processes, pandemics, International Classification of Functioning, Disability and Health, COVID -19 